\title{
BROOYAR ROCKSHELTER:A LATE HOLOCENE SEASONAL HUNTING CAMP FROM SOUTHEAST QUEENSLAND
}

\section{IAN MCNIVEN}

Anthropology \& sociology Univergity of Queensland

\section{INTRODUCTION}

This paper details the results of an excavation undertaken at Brooyar Rockshelter, southeast Queensland during August 1987. The rockshelter was excavated as part of a larger research project focused upon the adjacent coastal region of Cooloola (McNiven 1985) (Figure 1). The excavation had two main aims. The first was to establish a chronological framework for backed blades in the Gympie-Cooloola region, thus providing insight into the antiquity of non-stratified open sites with backed blades in the region (e.g. sandblow sites at Cooloola MCNiven 1985:15, 26, 28) (Cf. Hiscock 1986). The second aim was to obtain comparative information on subsistence activities located in the hinterland region of cooloola.

\section{THE SITE}

Brooyar Rockshelter is located within Brooyar state Forest approximately $10 \mathrm{~km}$ northwest of Gympie and some $55 \mathrm{~km}$ inland from the Cooloola coast (Figure 1). The shelter is part of a large elevated escarpment comprising Upper Triassic to Lower Jurassic Myrtle Creek sandstone (Murphy et a.1.1976:49-50). It is approximately 200m a.s.1. and overlooks Glastonbury Creek, a tributary of the Mary River (Figure 1). The site lies some $150 \mathrm{~m}$ above, and $900 \mathrm{~m}$ west of the creek.

The surface of the shelter is approximately $16 \mathrm{~m}$ long and $3 \mathrm{~m}$ deep. When first recorded the floor was littered with fragments of sandstone roof fallas well as a scatter of stone artefacts and bone fragments (Figure 2). At the western end, a number of roof fall fragments have been used for a modexn hearth. A huge sandstone block at the front of the shelter has aided the accumulation of sediments within the shelter (Figure 3). A few metres beyond the dripline the surface drops steeply away to the edge of the escarpment. A significant feature of the site is the existence of a low, narrow (0.5-1.0m) shelf extending along most of the back wall (Figure 3). This shelf provides protection from treadage for archaeological materials. 


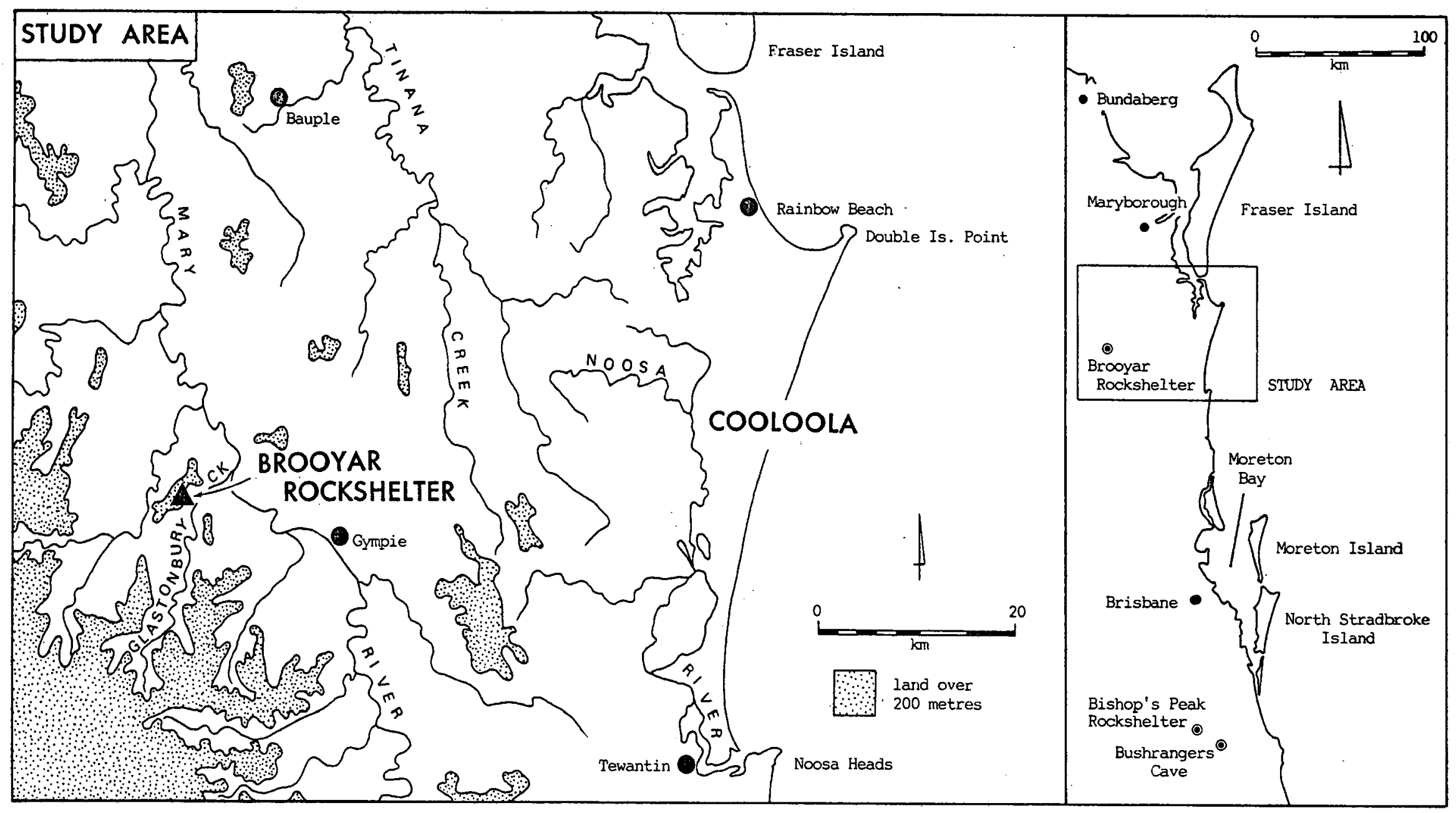

Figure 1. Map of S.E. Queensland and study area. 


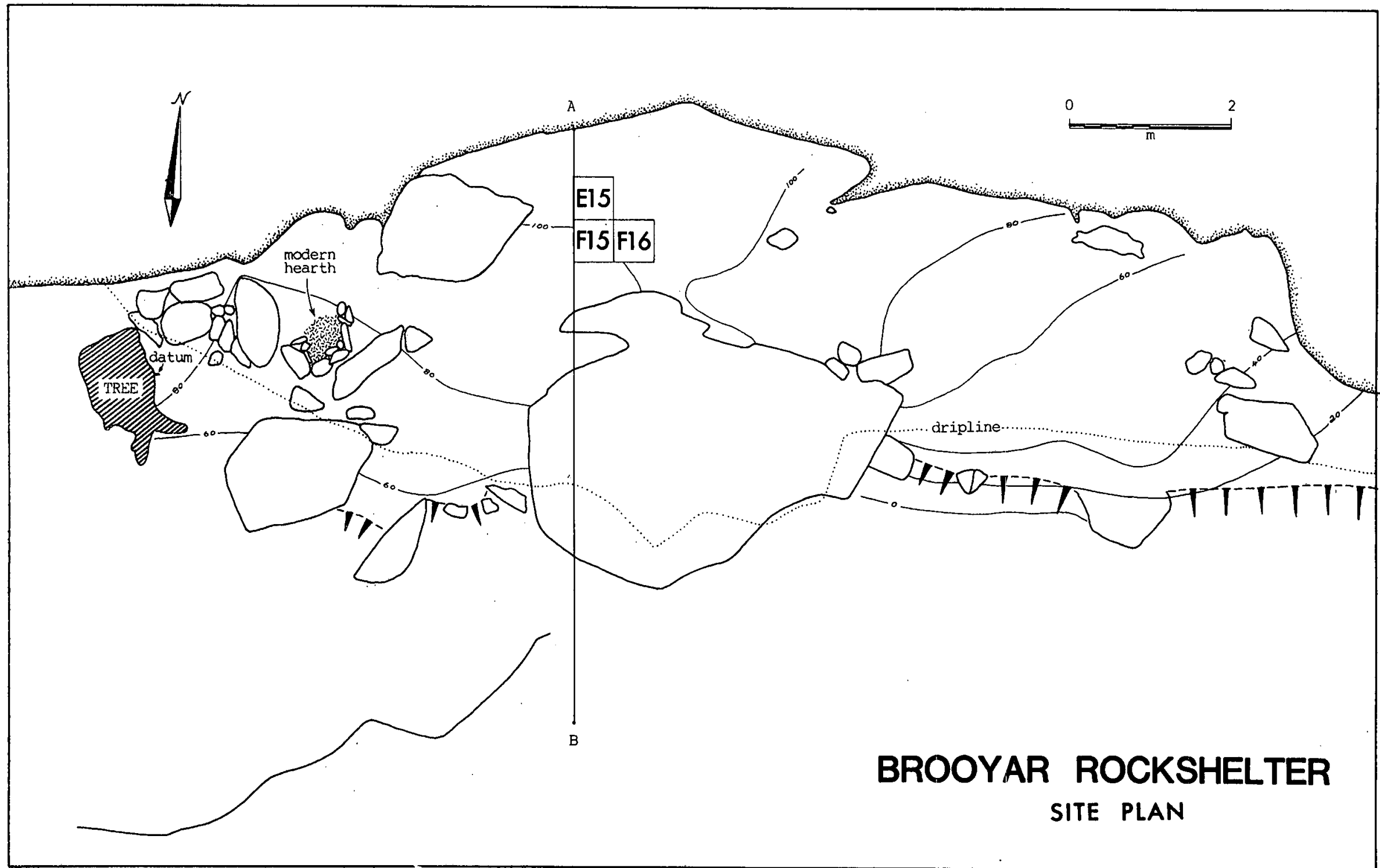

Figure 2. Site plan of Brooyar Rockshelter. 
The site is surrounded by open eucalypt forest which extends down the slope for approximately 100m. Prior to clearing for grazing and cultivation the lower sections of the glope and most of the valley bottom also carried open eucalypt forest (Ellis Betts, Glastonbury Creek valley, resident, pers. comm. 1988). Today, most of Glastonbury creek adjacent to the site is flanked by pockets of dense wet sclerophyll forest and rainforest.

\section{BROOYAR ROCKSHELTER}

\section{CROSS-SECTION}

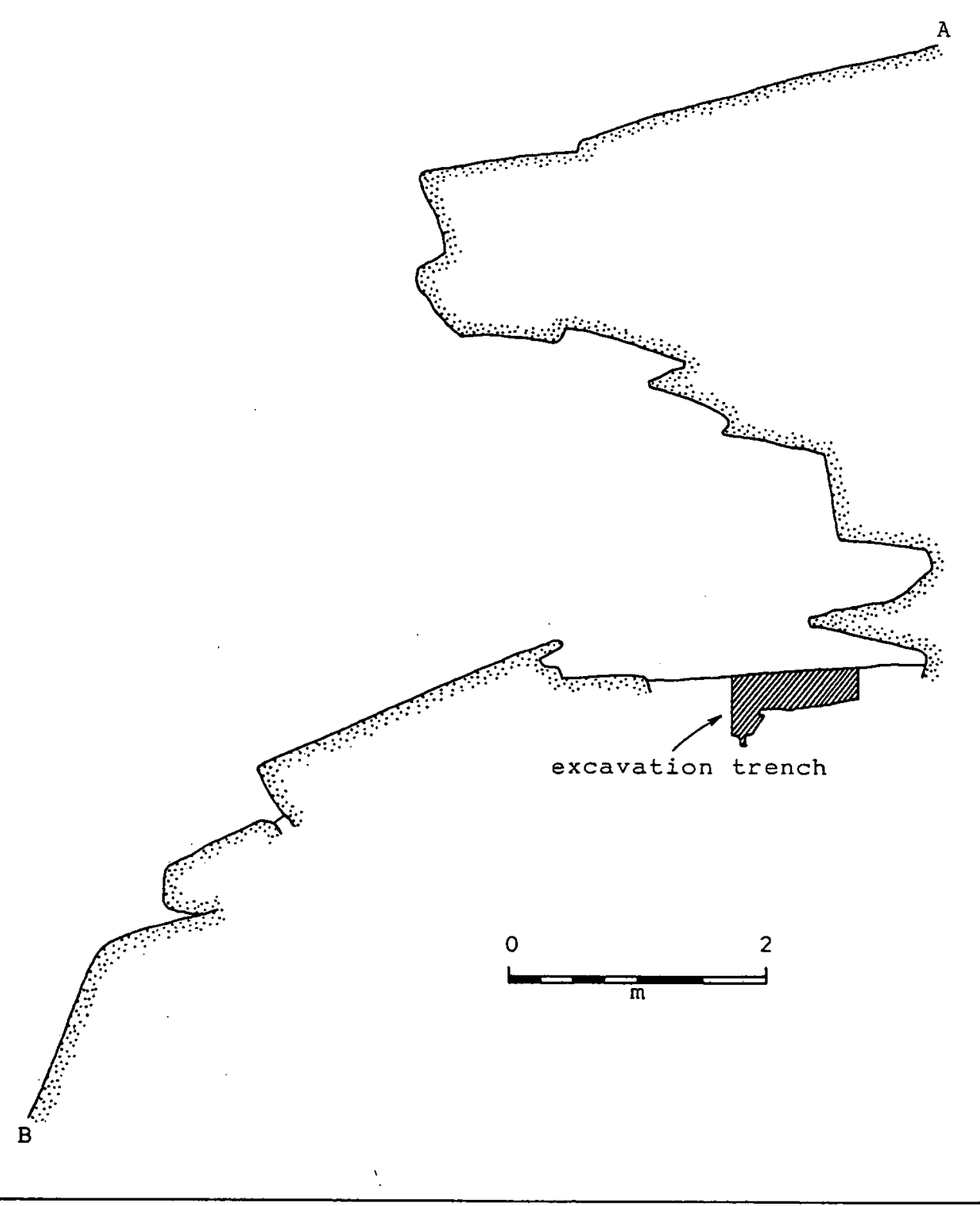

Figure 3. Cross-section of Brooyar Rockshelter 


\section{EXCAVATION PROCEDURE}

Prior to excavation an alphanumeric $50 \times 50 \mathrm{~cm}$ grid (aligned $85^{\circ}$ east - magnetic), was established over the site. The site datum (nail) was set in the base, of a large eucalypt tree at the western entrance to the shelter. Three contiguous grid units (E15, F15 and F16) forming an I-shaped trench were excavated. The trench was placed where roof fall appeared minimal, cultural remains appeared extensive, and a comparison of archaeological materials from both below and away from the protective shelf was considered possible. The trench was excavated using the 'bucket' technique devised by Johnson (1979). Each grid unit was excavated separately and each (10-litre) bucket of deposit usually constituted one Excavation Unit (XU). All XU's with cultural remains were collected in bulk. Culturally sterile $\mathrm{XU}^{\prime} \mathrm{s}$ were dry-sieved through $3 \mathrm{~mm}$ wire mesh in an area $10 \mathrm{~m}$ west of the site. Following excavation, the base of the trench was lined with plastic bags and backfilled.

\section{STRATIGRAPHY}

Four stratigraphic Unitg (SU) were identified (Figure 4). stratigraphic Units 1 to 3 were found in all grid unitg excavated, whereas su4 was only found in F15. The stratigraphy is as follows:

sul consigted of a relatively looge and homogeneous matrix of grayish brown (1OYR-5/2) silty sand and contained the buik of cultural remains recovered from the excavation. Numerous small tabular fragments of sandstone roof spall were found throughout. Leaf litter was mainly restricted to the surface. The $\mathrm{pH}$ values range from 6.5 to 8.5. Sul extended from the surface to ca. $10 \mathrm{~cm}$ over most of the trench, deepening to $14-17 \mathrm{~cm}$ at the southern and northern ends respectively. At the boundary of units $\mathrm{E} 15$ and F15, a small 'pit'. feature extended to a depth of $21 \mathrm{~cm}$ and represented the maximum depth observed for sul.

su2 was a relatively homogeneous matrix of brown (10YR-5/3), ioose, silty sand with a $\mathrm{pH}$ of 6.0. Cultural material was similar to that found in SU1, but less abundant. The nature and quantity of roof spall was also similar to that in sul. su2 was located beneath most of sul and reached a maximum thickness of $8 \mathrm{~cm}$ and a maximum depth of $21 \mathrm{~cm}$ below the surface (grid unit E15).

su3 was a relatively homogeneous matrix of loose, very pale brown (1OYR-7/4) silty sand with a number of discrete areas of organic staining.. At the base of grid unit E15 the sediment was extremely compacted. The unit yielded larger pieces of roof spall than found above and very little cultural material. The pH values range from 4.0 to 5.0. SU3 was located variously beneath sul and su2, and yielded a maximum thickness of $29 \mathrm{~cm}$ and a maximum depth of $39 \mathrm{~cm}$ below the surface (grid unit F15). Excavation of this unit was impeded in places by a series of large sandstone slabs.

su4 was culturally sterile, consisting of a relatively homogeneous matrix of compacted reddish yellow (7.5YR-7/6), silty sand with a pH of 4.5. Large pieces of roof spall were encountered throughout the unit. It was only observed in the southwest corner of grid unit F15 through a gap in the sandstone slabs. It lay beneath su 3 and commenced some $39 \mathrm{~cm}$ below the surface. Excavation of SU4 was arbitrarily gtopped after $23 \mathrm{~cm}$ at a depth of $62 \mathrm{~cm}$ 


\section{BROOYAR ROCKSHELTER STRATIGRAPHIC SECTIONS}
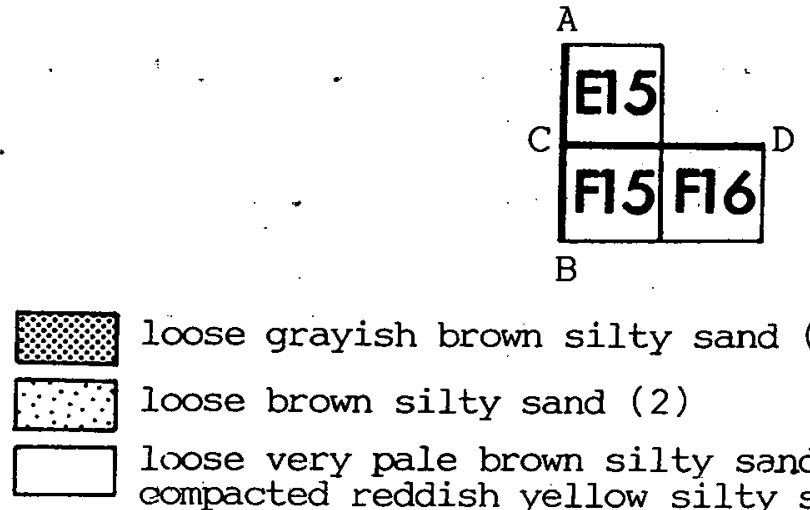

loose grayish brown silty sand (1)

loose brown silty sand (2)

loose very pale brown silty sand (3)

compacted reddish yellow silty sand (4)

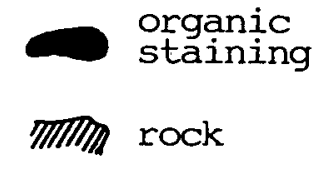

WEST

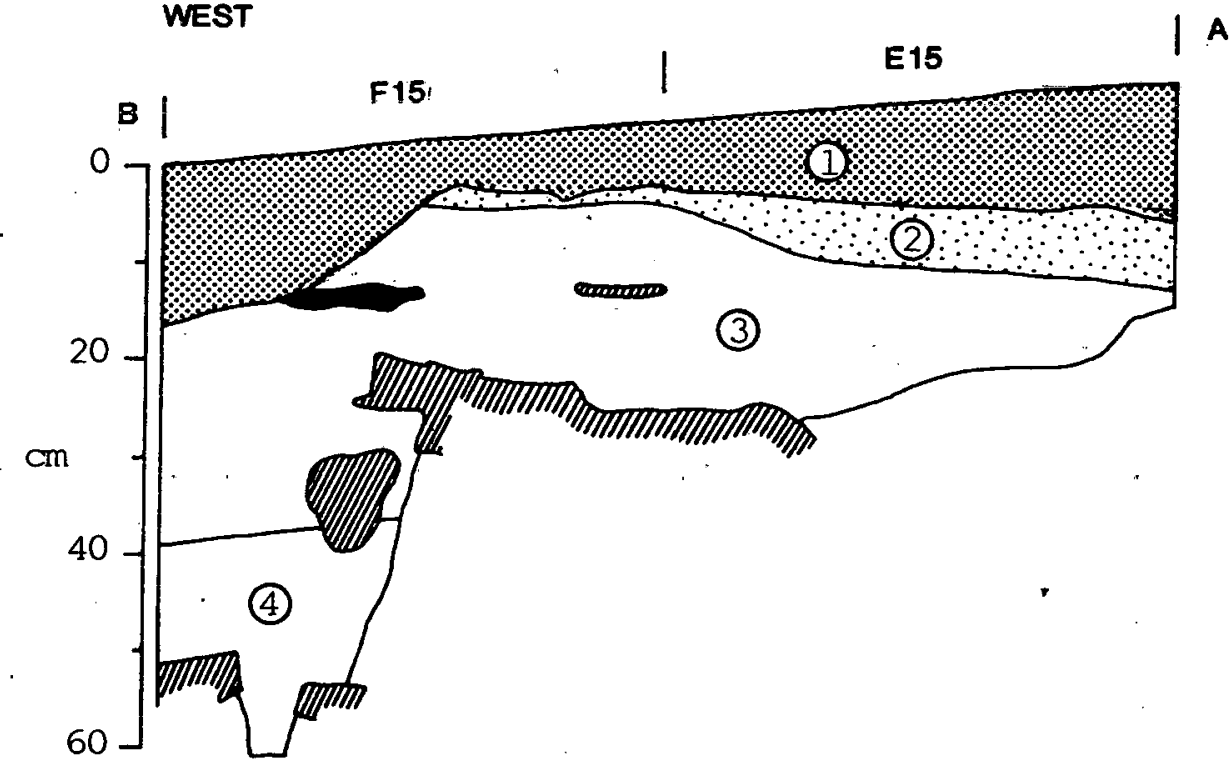

NORTH

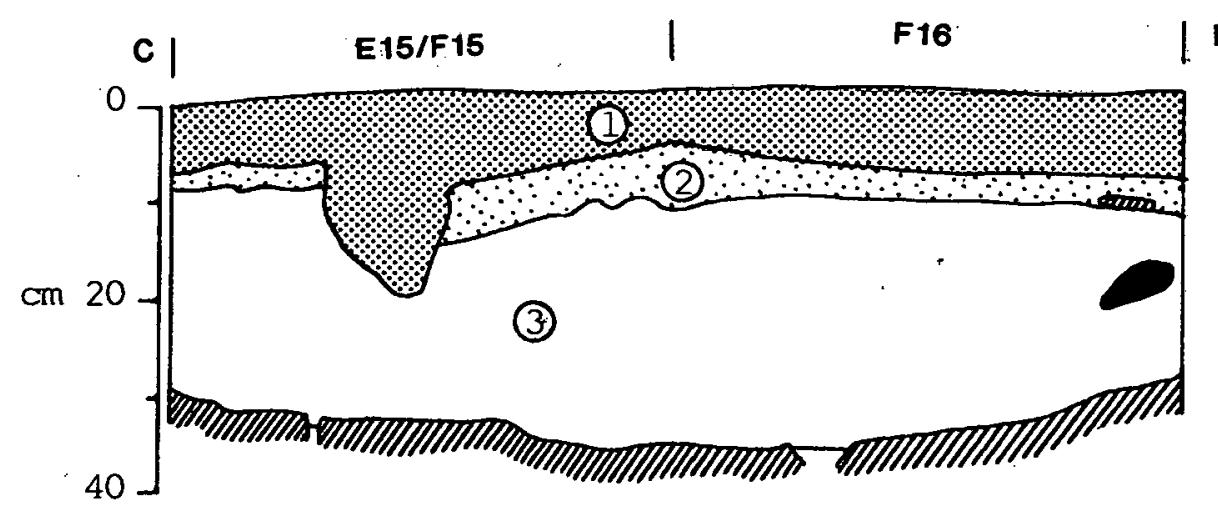

Figure4. Stratigraphic gections of excavation trench, Brooyar Rocksheiter. 
Despite apparent cultural deposition in three stratigraphic units, the uniformity, small volume and limited vertical extent of the cultural deposit are considered as a single unit for analytical purposes.

\section{DATING}

A near-basal age for sul was sought to determine the approximate commencement of human activity at the site. A $15 \mathrm{~g}$ sample of high quality wood charcoal from grid unit El5 (XU4) was submitted for radiocarbon age determination to Beta Analytic Inc. through the NWG Macintosh Centre for Quaternary Dating at the University of sydney. High stratigraphic integrity was assumed for grid unit E15 owing to its position beneath the protective shelf. Such a consideration was important given the shallowness and presumed sensitivity of sul to disturbance by treadage. Excavation Unit 4, located near the bottom of sul at a depth of $8-14 \mathrm{~cm}$, marks the commencement of a major increase in the density of cultural remains in the sequence, particulariy bones and stone artefacts (Figure 5).

The resulting age for $x U 4$ in radiocarbon years is $2650 \pm 60$ bp (Beta23344). This gives a calibrated age of 2762 BP with a two sigma range of 2729-2869 (20 year atmosphere record - stuiver and Reimer 1986) indicating that major human occupation of the shelter commenced ca. 2800 years ago.

\section{CULTURAI MATERIAL}

Cultural remains recovered from the site include stone artefacts, charcoal fragments, bones, egg shells, mollusc shells, seeds and fruit. In general, the relative amount of artefacts and organic remains decreases with depth (Figure 5). The cultural deposit was analysed as a single unit (see above).

\section{Vertebrate Fauna}

A total of 3836 bones (complete and fragmented) weighing $305.5 \mathrm{~g}$ was recovered from the excavation. A minimum of 14 taxa was identified,. nine to species level (Table 1). From the latter, a minimum of 10 individuals was identified (Table 1). The mammal assemblage was dominated by medium- to large-sized macropods (kangaroo, wallaby and pademelon) and small- to medium-sized quadrupeds (possum, bandicoot and koala).

\section{Taphonomic analygis}

A basic taphonomic analysis of the bone assemblage was undertaken to discern the degree to which it may have resulted from human activity. Recent taphonomic research has isolated four distinguishing features of humanly-derived faunal assemblages. They are larger mammals, exotic fauna, bone markings (e.g. cut marks) and burnt bone (Bowdler 1984, Binford 1981, Solomon 1985, Barker 1987, Colley 1987). 


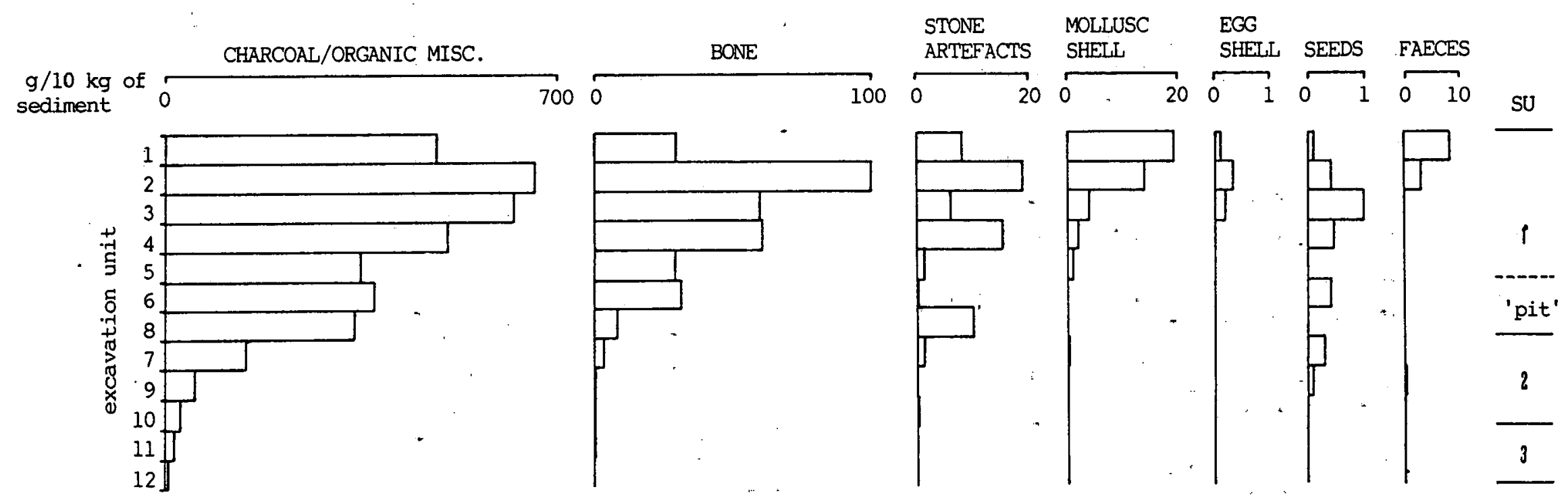

Figure 5. Vertical distribution of excavated finds from Brooyar Rockshelter. 
Table 1. MNI for vertebrate fauna identified from Brooyar - Rockghelter.

\begin{tabular}{llr}
\hline Scientific Name & \multicolumn{1}{c}{ Common Name } & MNI \\
\hline 1. Macropus giganteus & grey kangaroo & 1 \\
2. Thylogale gtigmatica & red legged pademelon & 1 \\
3. Thylogale thetis & red necked pademelon & 1 \\
4. Petrogale penicillata & brush-tailed rock-wallaby & 2 \\
5. Trichosurug vulpecula & brushtail possum & 1 \\
6. Pseudocheirug peregrinus & common ringtail & 1 \\
7. Phascolarctog cinerceus & koala & 1 \\
8. Isoodon macrourus & northern brown bandicoot & 1 \\
9. Melomys cervinipes & fawn-footed melomys & 1 \\
10. Pythoninae & python & 1 \\
11. Egernia & skink & 1 \\
12. Gekkonidae & gecko & 1 \\
13. Aves & bird & 1 \\
14. Michrochiroptera & bat & 1 \\
\hline
\end{tabular}

Burnt bone: It has been argued that bone assemblages with a high degree of burning, especially calcining, derive from human activity (Balme 1980, Shipman, Foster and schoeninger 1984, von Endt and Ortner 1984, David 1987). Bone can be burnt by humans from contact with hearths, either as a result of the superimposition of a hearth on previously discarded bones or through cooking (Hope et al. 1977, Barker 1987, see also Walters 1988). In this connection, the process of cooking joints of meat in hearths was recorded ethnographically in the Gympie district last century (Mathew 1887, 1910).

Some 278 of the bone fragments from Brooyar Rockshelter exhibit signs of burning and/or calcining (Table 2)." The burnt bone, and in particular the calcined bone, strongly suggest that humans were the major agent of bone deposition at the site.

Table 2. Amount of burnt bone at Brooyar Rockshelter.

\begin{tabular}{|c|c|c|c|c|c|c|c|c|}
\hline \multirow{3}{*}{ GRID } & \multicolumn{6}{|c|}{ BONE } & \multicolumn{2}{|c|}{ TOTAL } \\
\hline & \multicolumn{2}{|c|}{ Unburnt } & \multicolumn{2}{|c|}{ Burnt } & \multicolumn{2}{|c|}{ Calcined } & \multirow[b]{2}{*}{$\mathbf{n}$} & \multirow[b]{2}{*}{8} \\
\hline & $\mathrm{n}$ & 8 & $\mathbf{n}$ & 8 & $\mathbf{n}$ & 8 & & \\
\hline E15 & 1547 & 77.9 & 328 & 16.5 & 111 & 5.6 & 1986 & 100.0 \\
\hline F15 & 936 & 69.4 & 349 & 25.9 & 64 & 4.7 & 1349 & 100.0 \\
\hline F16 & 313 & 62.5 & 162 & 32.3 & 26 & 5.2 & 501 & 100.0 \\
\hline Total: & 2796 & 72.9 & 839 & 21.9 & 201 & 5.2 & 3836 & 100.0 \\
\hline
\end{tabular}

Teeth and cut marks:

All bones were examined under a Wild stereoscopic microscope with a zoom lens (12-60x magnification) for tooth and cut marks. No definite cut marks were identified, while eight bone fragments exhibited tooth marks. Half of the chewed bones showed signs of rodent incisors; the remaining four exhibited tiny 
canine marks, probably resulting from a small marsupial carnivore (e.g. Dasyurus sp.). No dingo teeth marks were observed. As neither rodents nor dasyurids hunt medium to large mammals, the evidence suggests a human origin for the Brooyar bone assemblage.

Fragmentation: Bones in archaeological contexts can be fragmented by both human and non-human agencies. (Hill 1976, Binford and Bertram 1977, Noe-Nygaard 1977, Solomon 1985, Todd and Rapson 1988). While a full analysis of fragmentation is beyond the scope of this paper, preliminary results suggest, that most bone fragmentation results from treadage and food (marrow) extraction by humans.

Solomon (1985) demonstrated that marrow-extraction by dingoes primarily destroys softer proximal and distal bone elements, leaving shafts largely intact. She also argued that bone fragmentation by human treadage is minimal, particularly for larger limb bones (solomon 1985:124-5). The bone assemblage at Brooyar Rockshelter is extremely fragmented, with over 908 of the bones measuring 1 ess than $2 \mathrm{~cm}$ in length (Table 3). Despite the identification of four medium- to largesized macropods at the site, no complete or even near complete sections of large limb bones were identified. Such a pattern suggests that purposeful human action was responsible for much of the bone fragmentation and that marrow extraction from macropod "limb bones was the major activity. "This inference accords well, with Petrie's observation that Aborigines in southeast Queensland "were especially fond of marrow as food" (1904:105).

The bone size data also indicate that treadage contributes to bone fragmentation at the site. Bones recovered from grid unit E15 under the protective-shelf exhibit a different degree of fragmentation from those found in grid units $F 15$ and F16, which are located in the treadage zone. For example, E15 contained $528(n=1986)$ of all excavated bone (Table 2), but $808,(n=24)$ of all bones longer than $4 \mathrm{~cm}$ and $1008(n=2)$ of all bones longer than $6 \mathrm{~cm}$. Similarly, the mean weight of bones in F15 and F16 is both $0.07 \mathrm{~g}$, while it is silghtly higher $(0.09 \mathrm{~g})$ for E15 (Table 4).

Table 3. Size classes of burnt and unburnt bone from Brooyar Rockshelter.

\begin{tabular}{|c|c|c|c|c|c|}
\hline \multirow{2}{*}{$\begin{array}{c}\text { size class } \\
(\mathrm{cm})\end{array}$} & \multirow{2}{*}{$\underset{n}{\text { unburnt }}$} & \multirow{2}{*}{$\begin{array}{c}\text { burnt } \\
n\end{array}$} & \multirow{2}{*}{$\begin{array}{c}\text { calcined } \\
n\end{array}$} & \multicolumn{2}{|c|}{ total } \\
\hline & & & & $\mathbf{n}$ & 8 \\
\hline $0-2$ & 2609 & 782 & 200 & 3591 & 93.6 \\
\hline$>2-4$ & 159 & 55 & 1 & 215 & 5.6 \\
\hline$>4-6$ & 26 & 2 & 0 & 28 & 0.7 \\
\hline$>6-8$ & 2 & 0 & 0 & 2 & 0.1 \\
\hline Total: & 2796 & 839 & 201 & 3836 & 109.0 \\
\hline
\end{tabular}

It is apparent that bones recovered from grid unit E15 are slightly less fragmented than those found in grid units F15 and Fib. A simple explanation for this difference is treadage, following initial fragmentation for marrow extraction. The relatively higher treadage fragmentation rates for unburnt bone in grid units F15 and F16 (Table 3), also suggest that burnt bone is not always more susceptible to treadage fragmentation (cf. Barker 1987). 
Table 4. Mean weights of unburnt, burnt and calcined bones for excavated grid units at Brooyar Rockshelter.

\begin{tabular}{ccccc}
\hline $\begin{array}{c}\text { Grid } \\
\text { Unit } \\
(g)\end{array}$ & $\begin{array}{c}\text { Unburnt } \\
\text { mean Wt } \\
(g)\end{array}$ & $\begin{array}{c}\text { Burnt } \\
\text { mean Wt } \\
(g)\end{array}$ & $\begin{array}{c}\text { Calcined } \\
\text { mean Wt } \\
(g)\end{array}$ & $\begin{array}{c}\text { TOTAL } \\
\text { mean Wt }\end{array}$ \\
\hline E15 & 0.09 & 0.10 & 0.03 & 0.09 \\
F15 & 0.05 & 0.10 & 0.03 & 0.07 \\
F16 & 0.07 & 0.09 & 0.03 & 0.07 \\
\hline
\end{tabular}

The agent(s) responsible for treadage fragmentation of bones at Brooyar Rockshelter is problematic. Since Aboriginal hunter-gatherers used the site, numerous Europeans have walked through it and faecal remains also attest the presence of goats. However, while Aborigines, Europeans and goats have all probably contributed to this kind of fragmentation, the relative influence of each remains unknown.

\section{Exotic mammals}

Archaeological faunal assemblages can be contaminated by the remains of animals that naturally died on the site. Of all the medium to large mamma 18 recovered from Brooyar Rockshelter, the brush-tailed rockwallaby is the only species known habitually to use rockshelters (Maynes and sharman 1983:211). Recent evidence indicates that this animal has a strong "preference for...sunny, northerly facing slopes" (Short 1982:245). The southerly aspect of Brooyar Rockshelter suggests that the chances of brush-tailed rock-wallabies frequenting and naturally dying at the site are minimal. Therefore, the apparent exotic nature of all medium to large mammals recovered from the site suggests that they were transported to the site by humans.

A human agency for the occurrence of small animals (melomys, snake, gecko, skink and bat) is not conclusive. Ail these animals are not only represented by fewer than 10 bones, but they also occur around the immediate vicinity of the shelter. Therefore, despite their potential edibility, little evidence exists for their procurement or consumption by humans.

\section{Mamma1 procurement}

The preliminary taphonomic analysis of the Brooyar Rockshelter bone assemblage argues for human procurement of the larger mammals. All these animals could have been obtained from the surrounding open eucalypt forest and the adjacent rainforest/wet sclerophyll forest flanking Glastonbury creek. Open eucalypt forest is the preferred habitat of grey kangaroos, brush-tailed rock-wallabies, northern brown bandicoots and koalas (Ride 1980, short 1982, Gordon 1983, Martin 1983), while red-legged pademelons prefer wet sclerophyll forest and rainforest (Mather 1976, Johnson 1980, Johnson 1983). Red-necked pademelons and brushtail possums occur in both open eucalypt forest and rainforest (Dwyer, Hockings and willmer 1979, Johnson 1980, How 1983). Ringtail possums occur in both open eucalypt forest and rainforest in close proximity to water courses (Thomson and Owen 1964, Mather 1976, Dwyer, Hockings and Willmer 1979). 
Egg Shell

A total of $1.1 \mathrm{~g}$ of fragmented, burnt and unburnt egg shell was recovered from the excavation. All fragments belong to the brush turkey (Alectura lathami), a species which prefers rainforest habitats, where they produce large ground nests of vegetable matter. The usual nesting season is from August to January, while the average clutch size is 1824 (Macdonald 1973,. Frith 1976, Beruldsen 1980, Pizzey 1980). The potential source of brush turkey eggs nearest to the shelter is the immediate surrounds of Glastonbury Creek (Ellis Betts, Glastonbury creek valley resident, pers. comm. 1988). It is from here that the eggs were most likely to have been collected at some time near end of the year. The very small amount of egg shell recovered does not suggest that brush turkey egg consumption at the site was a major activity.

\section{Mollusc shell}

Some $36.9 \mathrm{~g}$ of fragmented, burnt and unburnt mollusc shell, representing only five individual shells (MNI) were recovered from the excavation (Table 5). Four species are represented: the freshwater mussels Alathyria pertexta and cucumerunio novahollandiae, the freshwater gastropod plotiopsis balonnensis and the land snail Sphaerospira fraseri.

Table 5. uNI counts for Brooyar Rockshelter molluscs.

\begin{tabular}{lc}
\hline Species & MNI \\
\hline Alathyria pertexta & 1 \\
Cucumerunio novahollandiae & 1. \\
\hline Plotiopsis balonnensis & 1 \\
Sphaerospira fraseri & 2 \\
\hline
\end{tabular}

Land snails occur naturally in the vicinity of the shelter. As only two were recovered from the excavation, their presence is probably due to natural agents. The nearest potential source of freshwater mussel and freshwater gastropod is Glastonbury creek. It is apparent that these shells were procured by Aborigines and transported back to the shelter. Their low number indicates that freshwater mollusc consumption at the site was a minor activity.

\section{Macrofloral Remains}

A range of floral debris including leaf and twig fragments was recovered during excavation. From this material, 35 individual burnt and unburnt seeds (11 types) and two unburnt, dehydrated fruits (1 type) were identified as potential food remains. The only identifiable remains were seeds from the fruits/cones of yellow boxwood (Planchonella pohlmaniana) and hoop pine (Araucaria cunninghamii). Together these two plants account for 548 of all seeds recovered (Table 6).

Hoop pine is a very tall rainforest tree producing cones-composed of numerous small seeds. The cones ripen in December-January, and the 
seeds subsequently fall to the ground (Cameron 1958). The source of hoop pine trees nearest to Brooyar Rockshelter is the fringes of Glastonbury Creek, where large trees can still be found. It is unlikely these seeds would naturally blow into the shelter given its distance and elevation above the creek. It is more likely that they were collected by Aborigines and transported back to the shelter for consumption.

The degree to which hoop pine seeds were gathered and consumed is problematic. Individual seeds can be consumed whole or after husking, depending on preference. The completeness of most specimens recovered from the site suggests that de-husking did not occur and that seeds were simply eaten whole. Given that up to 6000 dry seeds can weigh less than one kilogram (Cameron 1958) it is apparent from the small sample from the site that hoop pine seeds were of minor dietary gignificance at Brooyar.

Tab1e 6. Seed and fruit types at Brooyar Rockshelter.

\begin{tabular}{|c|c|c|c|c|}
\hline & Type & $\mathbf{n}$ & 8 & Plant Name \\
\hline SEEDS : & 1 & 14 & 40.0 & Yellow Boxwood \\
\hline$\cdot \cdot \quad \cdot$ & 2 & 5 & 14.3 & Hoop Pine \\
\hline . & 3 & 1 & .2 .9 & $?$ \\
\hline$\cdot$ & 4 & 2 & $5.7=$ & $?$ \\
\hline ; & 5 & 2 & 5.7 & $?$ \\
\hline & 6 & 1 & 2.9 & $?$ \\
\hline & 7 & 3 & 8.6 & $?$ \\
\hline & 8 & 3 & 8.6 & $?$ \\
\hline & 9 & 2 & 5.7 & $?$ \\
\hline & 10 & 1 & 2.9 & $?$ \\
\hline & 11 & 1 & 2.9 & $?$ \\
\hline Total: & & 35 & 100 & \\
\hline FRUITS : & 1 & 2 & 100 & $?$ \\
\hline
\end{tabular}

Yellow boxwood is a fairly common rainforest tree in southeast Queensland and is often found in association with hoop pine. In October it produces plum-1ike fruits containing 3-5 seeds (Francis 1981, Williams 1984, Williams, Harden and MacDonald 1984). As for hoop pine, the nearest potential source of yellow boxwood is along Glastonbury Creek. It is probable that the fruits were col lected there and transported back to the shelter for consumption: As 14 yellow boxwood seeds only represent some 3-5 fruits, consumption of this fruit at the site was probably only a minor activity.

\section{Bone Artefact}

A 34mm-long bi-point was recovered from grid unit E15 (XU4) (Figure 6). It consists of compact shaft bone and is missing the tips from both ends. The middle section of the point is covered in resin exhibiting a number of tiny sub-parallel impressions which were probably made by twine. This evidence suggests that the point was once hafted with both ends left exposed. Although the specific function of this artefact is unknown, its form and inferred hafting technique is identical to spear 
tips recorded historically in many parts of Australia (e.g. Roth 1909, Davidson 1934, McCarthy 1940, 1976), possibly including nearby Fraser Island (Devitt 1980, Steele 1983).

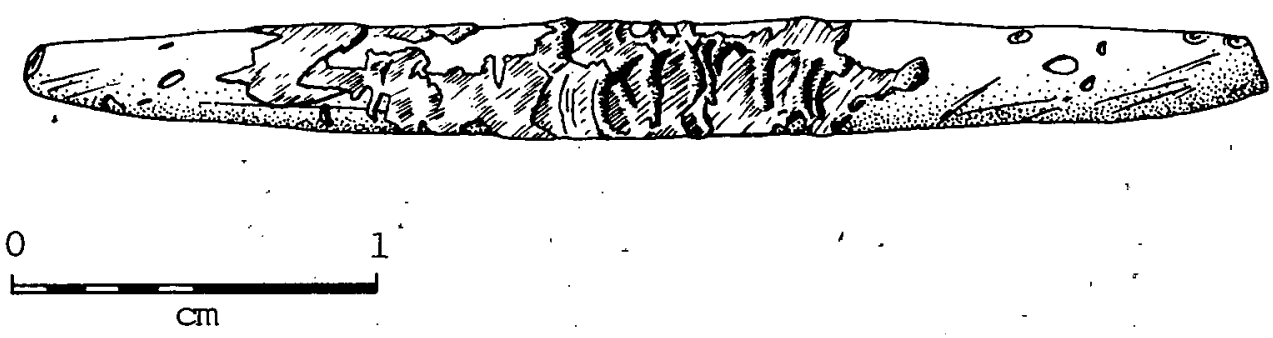

Figure 6. Bone bi-point with hafting resin from Brooyar Rockshelter.

\section{Shell Artefact}

The single diagnostic fragment of freshwater mussel shell (Cucumerunio novahol landiae) has been unifacially flaked for $54 \mathrm{~mm}$ along one margin to produce a serrated-edged implement (Figure 7 ). It is probable that it was used either as a scraper and/or a knife (see Mathew 1887:157, Petrie 1904:101, Spencer 1914:248, Schrire 1982:63, Cooper 1988). Detailed use-wear and residue analysis may provide further insights into the implement's function.

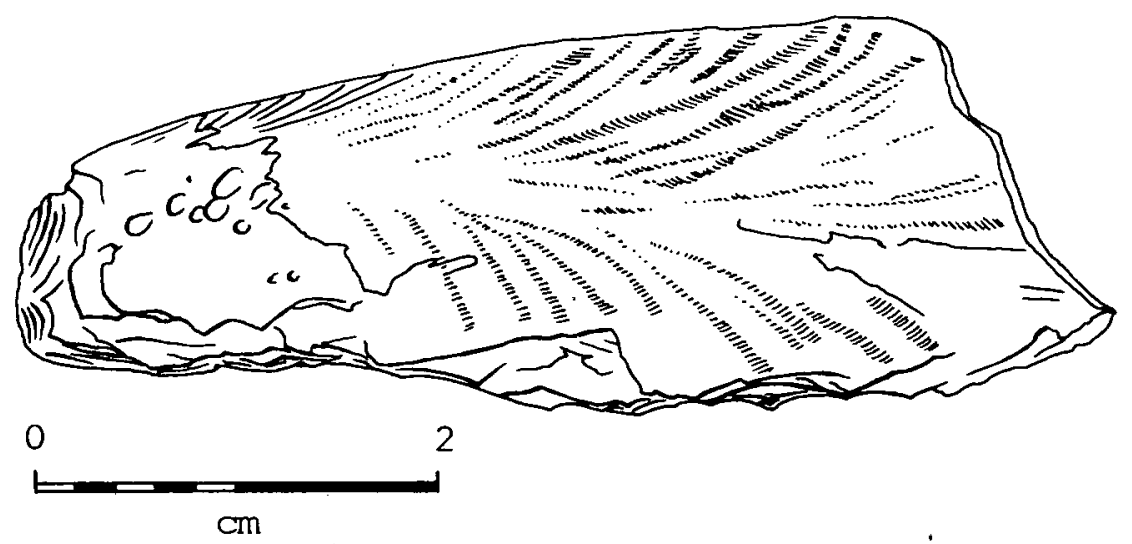

Figure 7. Flaked Cucumerunio novahollandiae shell from Brooyar Rockshelter.

\section{Stone Artefacts}

The 445 stone artefacts recovered from the site were classified into the major fracture categories of unbroken flakes, broken flakes and flaked pieces, cores, and retouched flakes (see Hiscock 1984). No manuports or grinding implements were recovered. The majority of stone artefacts were flakes and flaked pieces (96.68) (Table 7).

The major aim of the artefact analysis is to provide some insight into stone artefact technology at Brooyar. The number of metrical and non-metrical variables recorded for individual artefacts ranges from 23 for retouched flakes to only four for flaked pieces. Descriptive statistics were restricted to samples of 10 or more artefacts. 
Table 7. Relative frequency of stone artefact fracture types from Brooyar Rockshelter.

\begin{tabular}{lcc}
\hline Fracture Type & number & 8 \\
\hline unbroken flakes & 192 & 43.1 \\
broken flakes and & & \\
flaked pieces & 238 & 53.5 \\
cores & 4 & 0.9 \\
retouched flakes & 11 & 2.5 \\
- & & \\
Total: & 445 & 100.0
\end{tabular}

Raw material

Artefacts were manufactured from six raw material types. The predominate raw material is chert (88.88, $n=395)$, followed by basalt (3.88, $n=17)$, quartzite (3.18, $n=14)$, quartz (2.0, $n=9)$, gilcrete (2.08, $n=9$ ) and chal cedony (0.28, $n=1)$.

\section{Unbroken flakes}

The majority (86.58, $n=166)$ of unbroken flakes are made from chert and average only $0.6 \mathrm{~g}$ in weight and 1 ess than $10 \mathrm{~mm}$ in length and width. The remainder are made from basalt $(n=8)$, silcrete $(n=6)$, quartz $(n=6)$, quartzite $(n=5)$ and chalcedony $(n=1)$. Nearly 308 of flakes exhibit cortex, most representing secondary stages of decortication. Only one primary flake was recovered. Most (64.68) chert flakes exhibit overhang removal.

Over 758 of flake platforms show some evidence of preparation. Flaked platforms make up the majority. of these, with platform facetting being relatively insignificant (1.68). Platforms are generally small, as evidenced by the presence of focalized platforms (10.98) and a mean platform thickness and platform width of only $1.5 \mathrm{~mm}$ and $5.5 \mathrm{~mm}$ respectively. This small mean and the occurrence of focalized platforms suggests that very control led and precise knapping with low to moderate force took place at the site.

Grinding was observed on a single basalt flake. Numerous striations on a small area of the dorsal surface are consistent with those found on edge-ground axes. As basalt is a highly desirable raw material for making edge-ground axes, this flake probably derives from an axe.

\section{Broken flakes and flaked pieces}

A summary of all variables recorded on broken flakes and flaked pieces is presented in Table 8 . Over 908 of all stone artefacts are made from chert, while nearly 208 exhibit cortex. The mean length of unbroken flakes and flaked pieces is $9.8 \mathrm{~mm}$ and the mean weight only $0.3 \dot{g}$. 
Table 8. Summary data for broken flakes and flaked pieces from Brooyar Rocksheltèr.

\begin{tabular}{|c|c|c|c|c|c|c|c|c|}
\hline \multirow{3}{*}{$\begin{array}{c}\text { Raw } \\
\text { Material }\end{array}$} & \multirow{3}{*}{$\mathbf{n}$} & \multirow{3}{*}{8} & \multirow{3}{*}{$\begin{array}{c}\text { mean } \\
\text { Wt }\end{array}$} & \multicolumn{4}{|c|}{ Decortication Stages } & \multirow{3}{*}{$\begin{array}{l}\text { mean } \\
\text { length * }\end{array}$} \\
\hline & & & & sec & ndary & & iary & \\
\hline & & & & $\mathbf{n}$ & 8 & $\mathbf{n}$ & 8 & \\
\hline Chert & 216 & 90.8 & 0.3 & 42 & 19.4 & 174 & 80.6 & .9 .7 \\
\hline Basalt & 9 & 3.8 & - & 0 & - & 9 & - & - \\
\hline silcrete & 3 & 1.3 & - & 2 & - & 1 & - & - \\
\hline Quartzite & 8 & 3.4 & - & 0 & - & 8 & - & - \\
\hline Quartz & 2 & 0.8 & - & 1 & - & 1 & - & - \\
\hline Total: & 238 & 100 & 0.3 & 45 & 18.9 & 193 & 81.1 & 9.8 \\
\hline
\end{tabular}

* = maximum dimension

\section{Cores}

Only four cores were recovered. All are small, single platform bipolar cores weighing less than $10 \mathrm{~g}$ and averaging some $2 \mathrm{~cm}$ in length. cortex was only observed on the quartz core. Data recorded for each is presented in Table 9.

While many of the smali flakes recovered from the site probably result from overhang removal and retouching activities, the small size of cores suggests that many were purposefully manufactured. The recovery of a very'small $(0.2 \mathrm{~g})$ flake with adhering resin indicates that some of these artefacts may have been hafted. Small, unmodified hafted flakes have been historically documented as 'knives' in southeast queensland (Steele 1983:282-283) and southwest Western Australia (Mccarthy 1976:36), and as spear 'barbs' in north Queensland (Roth 1909:193), central New South Wales (Flood 1983:190) and southern South Australia (Angas 1847:Plate 6) (see Morwood 1986:107, 1987:347). While the use of small unmodified flakes at Brooyar Rockshelter as knives and/or pear barbs is only speculative, the suggestion is consistent with the hunting activities documented above. Use-wear and/or residue analysis may help resolve this question.

Table 9. Core data from Brooyar Rockshelter.

\begin{tabular}{lllllllll}
\hline $\begin{array}{l}\text { artefact } \\
\text { number }\end{array}$ & $\begin{array}{c}\text { Core } \\
\text { type }\end{array}$ & $\begin{array}{c}\text { Raw } \\
\text { material }\end{array}$ & $\begin{array}{c}\text { Wt } \\
\text { (g) }\end{array}$ & PT & PNo & $\begin{array}{c}\text { PD } \\
\text { (mm) }\end{array}$ & $\begin{array}{c}\text { CL } \\
\text { (mm) }\end{array}$ & $\begin{array}{c}\text { LFS } \\
\text { (mm) }\end{array}$ \\
\hline F15/1/59 & B & Quartz & 4.5 & C & 1 & $21 \times 12$ & 21 & 21 \\
$F 15 / 1 / 60$ & B & Chert & 1.8 & F & 1 & $10 \times 8$ & 20 & 16 \\
F16/1/77 & B & Chert & 8.7 & F & 1 & $18 \times 9$ & 24 & 24 \\
F16/1/78 & B & Chert & 1.9 & F & 1 & $14 \times 4$ & 18 & 18.
\end{tabular}

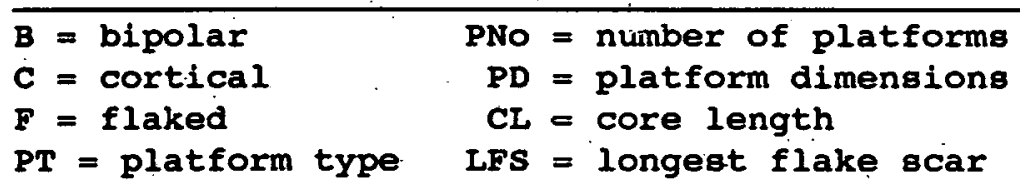


Retouched flakes

Eleven retouched flakes were recovered, including two adzes and nine amorphous retouched implements. Retouched, flakes range in weight from $0.5 \mathrm{~g}$ to $14.0 \mathrm{~g}$ with a mean weight of $4.3 \mathrm{~g}$. The mean length of retouching on individual artefacts is $43 \mathrm{~mm}$, while the mean length of a retouched margin is $20 \mathrm{~mm}$. Six retouched flakes exhibit intact platforms; all are either flaked $(n=3)$ or facetted $(n=3)$. Cortex was only observed on two artefacts.

Regularity in the production of amorphous retouched flakes was investigated by examining the location of secondary working. The number of retouched margins on flakes ranges from one to three. For the six retouched flakes exhibiting intact platforms, a total of 11 retouched margins was observed. Right and left flake margins each account for four with the remaining three occurring on distal flake margins. This pattern indicates that little preference existed for retouching particular margins.

In contrast to the peripheral location of retouching, the surficial location of retouching is highly patterned. Most (73.98) retouched margins are unifacially retouched onto the dorsal surface while only two artefacts exhibit bi-facial working. The strong preference for dorsal retouching may relate to the intended function of the implements. Sheridan (1979) has found that the convex ventral surface of woodworking adzes (tulas) increases the strength of the working edge. It is possible that similar mechanical considerations governed the surficial location of retouching on flakes at Brooyar Rockshelter. Use-wear analysis may provide further insight into this question.

The mean weight of retouched flakes is some seven times the mean weight of unmodified flakes. It is apparent that people were purposefully choosing larger flakes to modify by retouch into implements. From the high incidence of prepared platforms on all retouched flakes (especially facetted platforms) it may be inferred that the creation of larger flakes for subsequent retouching was deliberate and highly successful.

\section{Adze日}

Insight into the function of retouched implements is provided by the two adzes recovered from the excavation. Similar adzes, including tulas, have also been found on the surface in other parts of the shelter (McNiven in prep.). Their morphology (especially the tulas), coupled with the use-wear evidence (see Figure 8) indicates that these artefacts were probably used as wood working tools (see Sheridan 1979, Kamminga 1982 ).

\section{DIScussion}

\section{Subsistence strategies}

The excel lent preservation of organic remains at Brooyar Rockshelter provides insights into the possible range and relative significance of foods consumed at the site. The bulk of calories consumed at Brooyar Rockshelter derive from animals, in particular macropods. In contrast, 
plant foods constituted only a minor part of the diet. It may be inferred, therefore, that procurement strategies focussed upon the hunting of medium to large sized mammals from the surrounding open eucalypt forest, as well as the rainforest and wet sclerophyll forest fringing Glastonbury creek. In contrast, the small amounts of shellfish, birds' eggs and plants in the dietary assemblage indicate that consumption of these items was minimal.
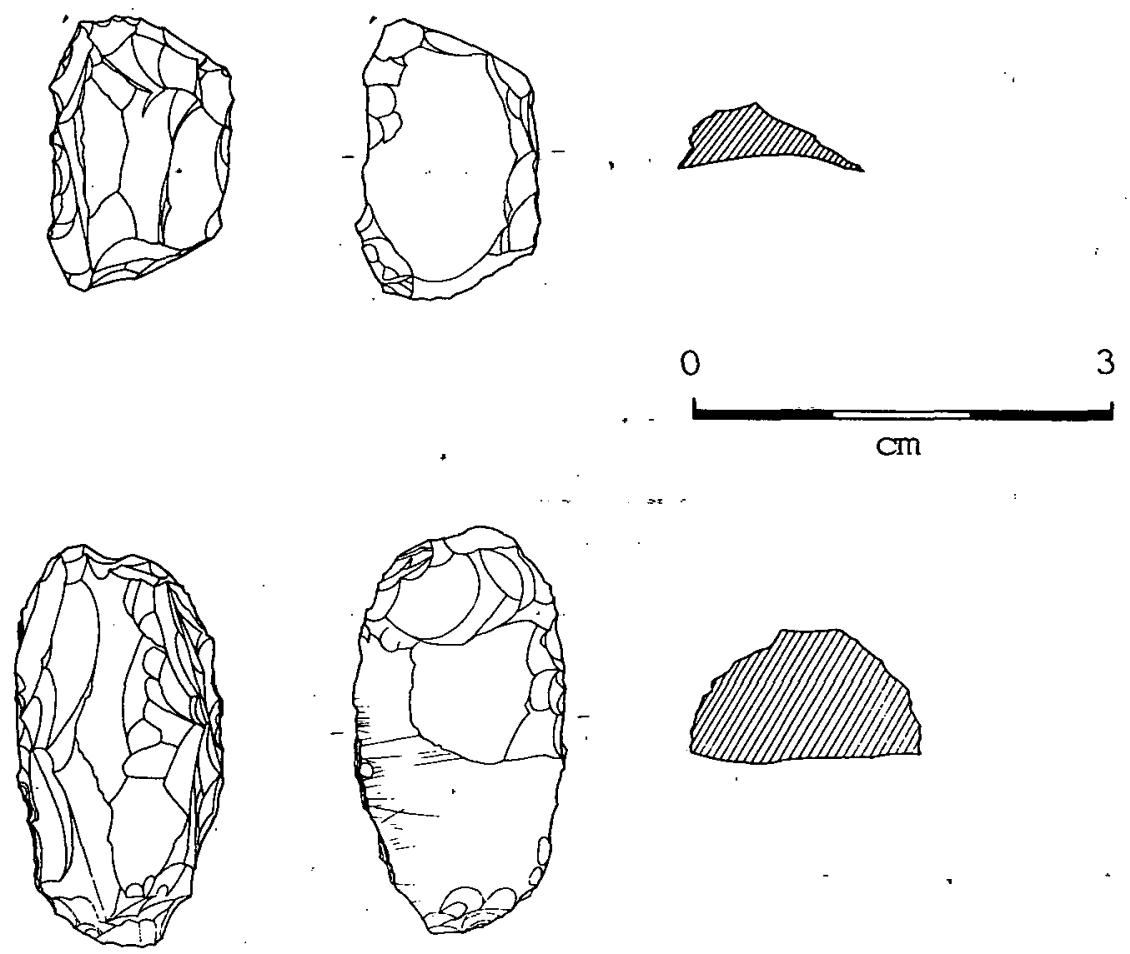

Figure 8. Adzes excavated from Brooyar Rockshelter

Top: Artefact No. F15/1/1 (use-wear polish on edge between arrows)

Bottom: Artefact No. F16/2/38 (use-wear striations on ventral surface)

\section{Ephemeral Hunting Camp}

The emphasis upon hunted animals in the Brooyar diet is not typical. for hunter-gatherers adapted to forested environments. Commenting on hunter-gatherers around the world, Lee states,

"...mammal hunting is the least reliable of the subsistence sources...most societies that rely primarily on mammals do so because their particular habitats offer no viable alternative subsistence strategy." (1968:42).

The Gympie district offers numerous plant food opportunities to hunter-gatherers, negating the need for prolonged dependence on animal foods. The plant food potential of the Gympie district is highlighted by the occurrence of Aboriginal bunya nut feasts in the area last century (Petrie 1904, sullivan 1977, see also Mathew 1887, 1910). It is unlikely. therefore, that the Brooyar diet is representative of the 
annual diet of late Holocene Aborigines in the Gympie district. On the dietary evidence alone Brooyar Rockshelter probably represents a very small component of the annual cycle of a group of people, and that the site was occupied only ephemerally during the year.

The ephemeral use of the site is corroborated by the incidence of dasyurid tooth marks on a number of bones. Dasyurids are timid animals, and would enter the shelter most likely after human abandonment (Steve van Dyke, Queensland Museum, pers. comm. 1988). Thus, tooth mark data support an inference that the site was occupied only periodically. Given the small quantity of cultural remains discarded at the site, it probable that the shelter only hosted a relatively small number of ephemeral occupational events in last 2800 years. The small size of the shelter may also suggest that the site only ever accommodated a small group of people.

It is probable that Brooyar Rockshelter functioned either as a small, ephemeral, specialized 'residential base camp' or a specialized mammal hunting transit field camp (see Binford 1980, 1982). Resolution of this question will involve comparative work on other sites in the Gympie district. At present, few data are available to make any reliable inferences in this regard.

\section{Seasonality and Resource Scheduling}

Direct evidence for seasonality of occupation (see Monks 1981) is provided by the brush turkey egg shell, hoop pine seed and yellow. boxwood seed. All three resources are temporally restricted to spring and summer. Assuming people consumed these foods soon after procurement, it is inferred that Brooyar Rockshelter was occupied sometime from August to January (a l though occupation can not be ruled out for other times of the year).

The seasonal use of sites is often determined by decisions concerning resource scheduling, which in turn are often determined by resource attributes (Jochim 1976:23). Twio major resources central to hunter-gatherer site location and occupation are fresh water and food (Vita-Finzi and Higgs 1970, Jochim 1976, 1981, Roper 1979, Foley 1981, Binford 1982, Sullivan 1982). The nearest major source of fresh water to Brooyar Rockshelter is Glastonbury Creek. The occupation of the site at a time when Glastonbury Creek is near its lowest level (October), indicates that food supply is more important than fresh water supply as a determinant of seasonal site occupation (Figure 9). It is likely, therefore, that the behaviour of macropods (kangaroos, wallabies and pademelons) and possums (ringtails, brushtails), the two dominant animal groups in the vertebrate faunal assemblage, may have been central to decisions concerning the seasonal use of the site.

Jochim argues that hunters tend to procure animals when they are relatively (seasonally) heavier, more aggregated and less mobile, to maximize energy efficiency and security of return (1976:15-19, 22-45, 1981:65-103, 143-147, see also Ellen 1982, speth and Spielmann 1983, Keene 1985). Information concerning seasonal variations in the condition and/or behaviour of macropods and possums consumed at Brooyar Rockshelter is only available for grey kangaroos, ringtail possums and brushtail possums. During the wet season, grey kangaroos and brushtail possums are more abundant, grey kangaroos and ringtail possums are more aggregated, while ringtail possums gain.up to 258 in body weight 
(Thomson and Owen 1964, Dennet 1964, southwel1 1984, 1987). Along Glagtonbury creek, 428 of the mean annual rainfall falls in summer, while only 13\% falls in winter (Figure 9). Iike most of the sub-coastal southeast queensland, winter is a period of relative water stress (see Lilley 1984:12-13). It is probable therefore, that along Glastonbury Creek valley during the summer 'wet' season, grey kangaroos, brushtail possums and ringtail possums were more desirable prey to Aborigiries. The seasonal use of Brooyar Rockshelter probably results from scheduling decisions based on the summer 'wet' season increase in condition of mammal resources surrounding Glastonbury Creek (see sullivan 1977:6, Draper 1980:127). The use of the site as a short-term mammal hunting site during summer, coupled with its location adjacent to a major tributary of the Mary:River, accords with the predictions of Lilley's (1984) settlement-subsistence model for late Holocene sub-coastal southeast Queensland.

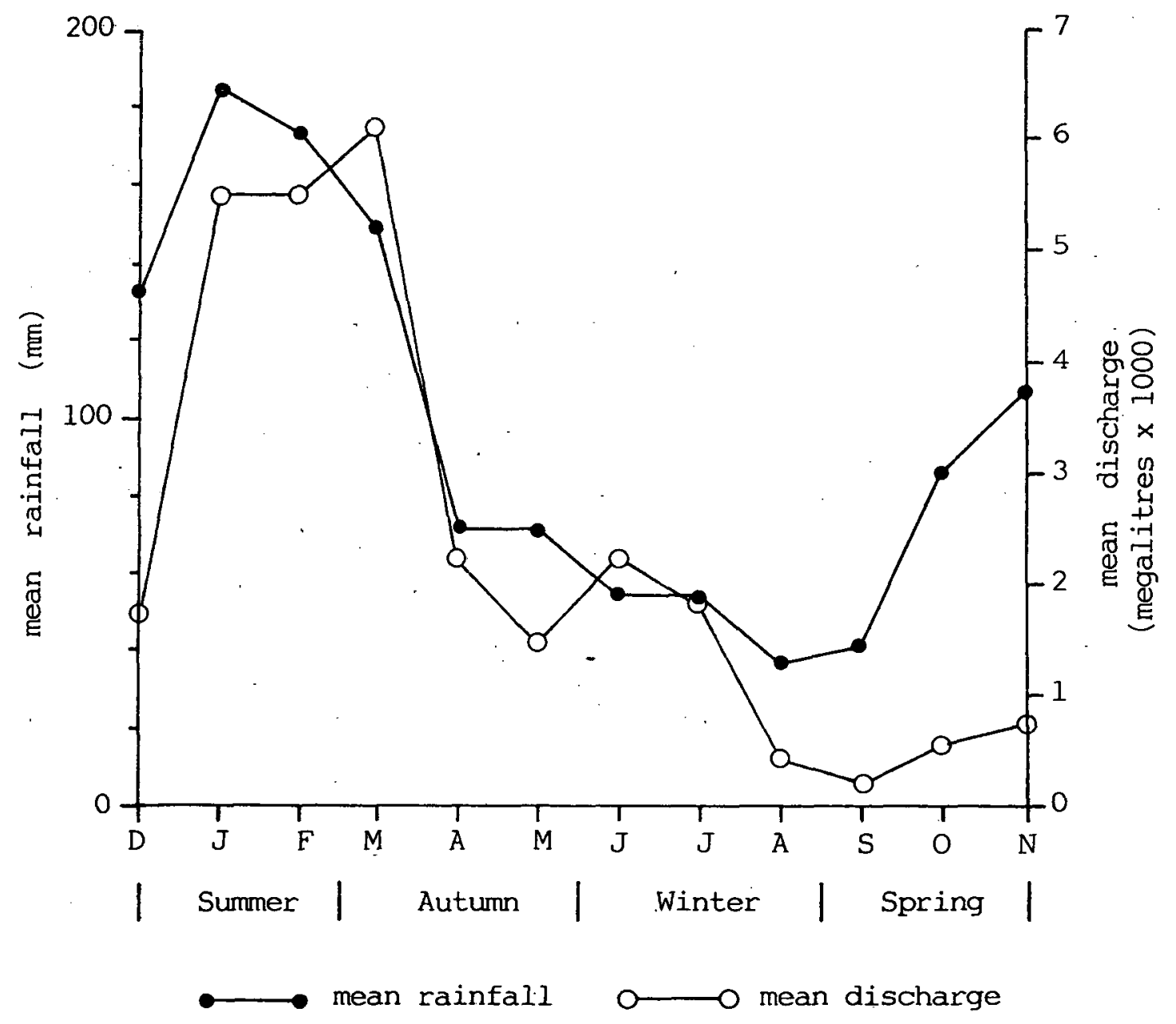

Source: Rainfall data (Bureau of Meteorology)

Discharge data (Water Resources Commission)

Figure 9. Mean monthly rainfall and discharge for Glastonbury Creek. 
It is generally argued that composite spears barbed with backed blades were the major item of material culture used to procure macropods in sub-coastal southeast Queensland and northeastern New south wales from ca. 3000-1000 years ago (McBryde 1976, Edmonds 1986, Morwood 1986, Boot 1988). At Brooyar Rockshelter no evidence for the manufacture or use of backed blades was encountered. Assuming spears were the weapon used by Aborigines at Brooyar Rockshelter to hunt macropods, it may be speculated that bone points and perhaps small, unmodified flakes acted as functional substitutes for backed blades. Use-wear analysis of larger samples of similar artefacts from Brooyar Rockshelter may help resolve this question.

The small axe fragment recovered from the excavation indicates that axe modification and possible maintenance occurred at Brooyar Rockshelter (cf. Edmonds 1986:80). Ringtail possums and especially brushtail possums commonly nest in hol low trees and logs (Dennet 1964, Thomson and Owen 1964, McKay 1983). In the Gympie district.last century, axes were recorded being used by Aborigines to extract possums from hollow trees (Mathew 1910:88, see also Petrie 1904:86-87). Given that possums were part of the food assemblage at the site, it can be speculated that the recovered axe fragment results from the maintenance of a possum procurement item (cf. McBryde 1976, Morwood 1986). The axe-possum hypothesis may be further tested by examining the nature of use-wear on axes and the association between possums and axes in a large sample of sites.

It was suggested above that the adzes recovered from Brooyar Rockshelter were used for wood working. As it has already been suggested that mammal hunting was the major activity represented at the site, it is probable that adzes were used in the manufacture and maintenance of mammal procurement artefacts (e.g. "spears etc.).

Sub-coastal studies

Brooyar Rockshelter expands upon findings in Bushrangers Cave (Hall 1986), Bishop's Peak rockshelter (Edmonds 1986) and Gatton Shelter (Morwood 1986, 1987) concerning mid-to late Holocene settlement and gubsistence behaviour in the mountainous hinterland of southeast Queensland. A common feature of these sites is the exploitation of food resources from wet sclerophyll forest/rainforest-open forest ecotones, with hunting activities focused upon macropods and, in particular, wàl labies and pademelons. At present, it remains uncertain how representative this subsistence strategy is in relation to other areas of sub-coastal southeast Queensland. All inferences have been based on a limited number of sites located in relatively atypical contexts (i.e. rockshelters, see Hall 1986:100) exhibiting uncommonly good preservation of organic remains. Additional open site surveys such as those initiated by Lilley (1982, 1985) and Gillieson (1981) are required to provide representative samples of other site types and site locations, before general statements can be made about sub-coastal settlement and subsistence in southeast queensland.

\section{Comparisons with cooloola}

A major reason for excavating Brooyar Rockshelter was to obtain a sample of backed blades in a datable context to shed light on the possible antiquity of these implements on non-stratified open sites in 
the Gympie-cooloola ragion. The absence of backed blades from the excavated finds precludes such chronological insights. The recent discovery and excavation of a stratified stone artefact site with a possible backed blade component at cooloola has produced more fruitful results (see McNiven 1988 ).

Brooyar Rockshelter yielded a terrestrial faunal assemblage deposited from ca. 2800 years ago. In contrast, specialized marine faunal assemblages dating to the last 1000 years characterize Cooloola, which is located less than $50 \mathrm{~km}$ to the east (MCNiven 1988). Both areas, therefore, exhibit regionally specialized subsistence strategies commencing in the late Holocene. At present, the causes of these recent developments and the nature of the association between them remains unknown. Future research will be directed towards resolving these problems and comparing. the results with recent explanations of late Holocene cultural change in southeast Queensland (Hall 1982, 1986, Hall and Robins 1984, Morwood 1986, Nolan 1986, Hall and Lilley 1987, Walters 1987, Walters et al. 1987, and in other parts of Australia (e.g. Attenbrow 1982, Lourandos 1985, Ross 1985, Hiscock 1986).

\section{ACKNOWLEDGMENTS}

Special thanks to the Queensiand state Forestry Department for granting me permision to excavate the site. George Venz (Gympie Forestry office) kindly informed me about the existence of the rockshelter and Mark Wren (Brooyar Forestry office) gave assistance during the project. Fieldwork was made possible by the efforts of Bryce Barker, Kathy Frankland and Geoff Smith. The following people from the queensland Museum freely gave assistance with the identification of faunal remains: Steve van Dyke (mammals), John stanisic and.Darryl Potter (molluscs), Wayne Longmore (birds), Patrick Couper and Glen Ingram (reptiles). Bryce Barker kindly assisted with the identification of tooth marks on bones. Thanks also to Laurie Jessup and Gordon Guymer (Queensland Herbarium) for identification of floral remains. Ian Lilley, J. Hall, Harry Lourandos, Peter Hiscock, Bryce Barker and Norma Richardson provided helpful comments on earlier drafts of this paper. Errors in fact or interpretation are, of course, solely my responsibility.

\section{REFBRENCES' CITTED}

Angas, G. F. 1847 South Australia Illustrated. London: Thomas McLean.

Attenbrow,v. 1982 The archaeology of Upper Mangrove creek catchment: research in progress. In s. Bowdler (ed), Coastal Archaeology in Bastern Australia, pp. 67-78. Department of Prehistory, Research School of Pacific studies, Australian National University.

Bálme, J. 1980 An analysis of charred bone from Devils Lair, Western Australia. Archaeology and Physical Anthropology in Oceania $15: 18-25$.

Barker, B. 1987 Narcurrer: An analysis of the vertebrate faunal assembiage. Unpublished B.A. (Hons) thesis, Univergity of Queensiand. 
Beruldsen, G. 1980 A field guide to nests and eggs of Australian birds. Rigby: Sydney.

Binford, L. R. 1980 Willow smoke and dog's ta11s: hunter-gatherer settlement systems and archaeological siterformation. American Antiquity 45(1):4-20.

Binford, L. R. 1981 Bones: ancient men and modern myths. New York: Academic Press.

Binford, L. R. 1982 The archaeology of place. Journal of Anthropological Archaeology 1:5-31.

Binford, I. R. 1983 In Pursuit of the Past. Iondon: Thames and Hudson.

Binford, I. R. and J. B. Bertram 1977 Bone frequencies and attritional processes. In L.R. Binford (ed) For theory building in archaeology, pp. 77-153. New York: Academic Press.

Boot, P. 1988 A functional analygig of the backed blade component of level 111A, Bendemeer 1. Paper presented to the second New England Archaeological Symposium: Technological Analysis and Australian Archaeology, 3rd-5th April.1988, University of New England, Armidale.

Bowdler, S. 1984 Hunter Hill, Hunter Island. Terra Australis 8. Department of Prehistory; : Regearch School of.Pacific studies, Australian National University.

Cameron, M. A. 1958 The flowering and fruiting of Hoop Pine. Queenaland Naturalist $16(1$ and 2$): 23-26$.

Colley, S. M. 1987 Humans as taphonomic agents." Papex presented at the Taphonomy of Bones Conference, 218t-22nd February 1987, University of New England, Armidale.

Cooper, z. 1988 shell artefacts from the Andaman Islands. Australian Archaeology $26: 24-41$.

David, B. 1987 Animals have to die sometime, or is this burnt bone burnt. Paper presented at the Taphonomy of Bones Conference, 218t-22nd February 1988, University of New England, Armidale.

Davidson, D. S. 1934 Australian spear-traits and their.derivation. Journal of the Polynesian Society 43:41-72, 143-162.

Dennet, G. M. 1964 A field study of local populations of the brushtailed possum Trichosurug vulpeculia in eastern Australia. Proceedings of the zoological society of London 142:665-695.

Devitt, J.1980 Fraser Island material cultural. Oniversity of Queensland Anthropology uuseum occasional papers in Anthropology 10:9-22.

Draper, N. 1980 Food resources of the Horeton Bay Aborigines. University of Queensland Anthropology Museum Occasional Papers in Anthropology 10:124-147. 
Dwyer, P. D., M. Hockings and J. Willmer 1979 Mammals of Cooloola and Beerwah. Proceedings of the Royal society of Queensland $90: 65-84$.

Edmonds, V. J. 1986 subtropical rainforest: archaeological evidence of Aboriginal use in the border ranges, southeast Queensland. Unpublished Master of Letters thesis, University of New England.

Ellen, R. 1982 Environment, subsistence and system. Cambridge: Cambridge University Press.

Flood, J. 1983 Archaeology of the Dreamtime. Sydney: Collins.

Foley, R. 1981 A model of regional archaeological structure. Proceedings of the Prehistoric society 47:1-17.

Francis, W. D. 1981 Australian rain-forest trees. Canberra: Australian Government Publishing Service.

Frith, H. J. (ed) 1976 Readers' Digest complete book of Australian birds. Sydney: Readers Digest Services Pty Ltd.

Gillieson, D. S. 1981 Aboriginal sites of the Albert Valley Southeast Queensland. Cultural Resource Management Monograph Series Number 3, Archaeology Branch, Queensland.

Gordon, G. 1983 Northern Brown Bandicoot. In R. Strahan (ed), The Australian Museum Complete Book of Australian Mammals, pp. 96-97. London: Angus and Robertson Publishers.

Hall, J. 1982 Sitting on the crop of the bay: an historical and archaeological sketch of Aboriginal settlement and subsistence in Moreton Bay. In S. Bowdler (ed), Coastal Archaeology in Bastern Australia, pp. 79-85. Department of Prehistory, Regearch school of Pacific studies, Australian National University.

Hall, J: 1986 Exploratory excavation at Bushrangers Cave (site LA:A11), a 6000-year-old camprite in southeast queensland: preliminary results. Australian Archaeology 22:88-103.

Hall, J. and R. Robins, 1984 A working model of Moreton Island prehistory: MRAP stage 1. Queensland Archaeological Research $1: 85-94$.

Hall, J. and I. Lilley, 1987 Excavations at the New Brisbane Airport site (LB:C69): evidence for early mid-Holocene coastal occupation in Moreton Bay, SE Queengland. Queensland Archaeological Research 4:54-79.

Hill, A.1976 On carnivore and weathering damage to bone. Current Anthropology $17(3): 335-336$.

Hiscock, P. 1984 Preliminary report on the stone artefacts from Colless Creek Cave; Northwest Queensland. Queensland Archaeological Research 1:120-151. 
Hiscock, P. 1986 Technological change in the Hunter River.valley and its implications for the interpretation of late Holocene change in Australia. Archaeology in Oceania 21(1):40-50.

Hope, J., R. J. Lampert, E. Edmondson, M. J. Smith and G. P. van Tets 1977 Late pleistocene faunal remains from seton rockshelter, Kangaroo Island. Journal of Biogeography 4:363385 .

How, R. A. 1983 Common Brushtail Possum. In R. Strahan (ed), The Australian Museum Complete Book of Australian Mammals, pp. 147-148. London: Angus and Robertson Publishers.

Jochim, M. A. 1976 Hunter-gatherer subsistence and settlement: a predictive model. New York: Academic Press.

Jochim, M. A. 1981 Strategieg for Survival: Cultural Behaviour In an Ecological Context. New York: Academic Press.

Johnson, I. 1979 The getting of data. Unpublished'Ph.D. thesis, Australian National University.

Johnson, K. A. 1980 spatial and temporal use of habitat by the Rednecked pademelon Thylogale thetis (Marsupialia: Macropodidae). Australian Wildlife Research 7:157-166.

Johnson, P. M. 1983 Red-legged Pademelon. In R. Strahan (ed), The Australian Museum Complete Book of Australian Mammals, p. 225. London: Angus and Robertson Publishers.

Kamminga, J. 1982 over the edge: functional analysis of Australian stone tools. University of Queensland Anthropology Museum Occasional Papers in Anthropology 12.

Keene, A. S. 1985 Nutrition and economy: models for the study of prehistoric diet. In R.I. Gilbert and J.H. Mielke (eds), The analysis of prehistoric diets,. pp. 155-190. Orlando: Academic press.

Lee, R. D. 1968 what hunters do for a living, or, how to make out on scarce resources. In R.D. Lee and I. Devore (eds), Man the Hunter, pp. 30-48. New York: Aldine.

Lilley, I. 1982 A finger on the pulse. Unpublished MA thesis, University of Queensland.

Lilley, I. 1984 Late Holocene subsistence and settlement in subcoastal southeast Queensland. Queensland Archaeological Research 1:8-32.

Lilley, I. 1985 An experiment in statistical location analysis in sub-coastal southeast queensland. Australian Archaeology 21:91-112.

Lourandos, H. 1985 Intensification and Australian Prehistory. In T.D. Price and J.A. Brown (eds), Prehistoric Bunter-gatherers: The Emergence of Cultural Complexity, pp. 385-423. Orlando: Academic Press. 
Macdonald, J. D." 1973 Birds of Australia. Sydney:A.H. and A.W. Reed.

Martin, R. W. 1983 Koala. In'R. Strahan (ed), The Australian Huseum Complete Book of Australian Mamma 18, pp. 113-115. London: Angus and Robertson Publishers.

Mather, P. 1976 The National Bstate in the Moreton and wide BayBurnett regions, south-east queensland and recommendations on its management. Brisbane: The Queensland Museum.

Mathew, J. 1887 Mary River and Bunya Bunya country. In E.M. Curr (ed), The Australian Race, pp. 152-209. Melbourne: Government Printer.

Mathew, J. 1910 Two Representative Tribes of Queensland. London: T. Fisher Unwin.

Maynes, G. M. and G. B. Sharman 1983 Brush-tailed Rock-Wallaby. In R. Strahan (ed), The Australian Mugeum Complete Book of Australian Mammals, pp. 211-212. London: Angus and Robertson Publisherg.

McBryde, I. 1976 subsistence patterns in New England prehistory. University of Queensland Anthropology Museum Occasional Papers in Anthropology $6: 48-68$.

McCarthy, F. D. 1940 The bone point known as Muduk, in eastern Australia. Records of the Australian Mugeum 20:314-19.

McCarthy, F. D. 1976 Australian Aboriginal stone Implements. Sydney: The Australian Museum Trust.

McKay, G. M. 1983 Common Ringtail Possum. In R. Strahan (ed), The Australian Museum Complete Book of Australian Mammals, pp. 126-27. London: Angus and Robertson Publishers.

MCNiven, I. 1985 An archaeological survey of the Cooloola region, S.E. Queensland. Queensland Archaeological Research 2:4-37.

McNiven, I. 1988 The effects of raw material proximity upon stone artefact assemblages along the cooloola coastline, s.E. Queensiand. Paper presented to the 2 nd New England Archaeological symposium: Technological Analysis and Australian Archaeology, 3rd-5th April 1988, University of New England, Armidale.

McNiven, I. in prep. Tula adzes and bi-facial points on the East coast of Australia.

Monks, G. G. 1981 Seasonality studies. Advances in Archaeological Hethod and Theory $4: 177-240$.

Morwood, M. J. 1986 The archaeology of art: excavations at Maidenwell and. Gatton shelters, southeast queensland. Queensland Archaeological Regearch 3:88-132.

Morwood," M. J. 1987 The archaeology of social complexity in south-east Queensland. Proceedings of the Prehistoric society 53:337350 . 
Murphy, P. R., H. Schwarzboch, L. C. Cranfield, I. W. Withnall and C.G. Murray 1976 . Geology of the Gympie 1:250 000 sheet map. Geological survey of Queensland Report No. 96.

Noe-Nygaard, N. 1977 Butchery and marrow fractures as a taphonomic factor in archaeological deposits. Paleobiology 3:218-237.

Nolan, A. 1986 Sandstone Point: temporal and spatial patterns of Aboriginal site use at a midden complex, aouheast Queerisland. Unpublished B.A. (Hons) thesis, University of Queensland.

Petrie, C. C. 1904 Tom Petrie's Reminiscences of Barly Queensland. Brisbane: Watson and Furguson.

Pizzey, G. 1980 A field guide to the birds of Australia. Sydney: Collins.

Ride, W. D. L. 1980 A Guide to the Hative Mammalg of Australia. Melbourne: Oxford University Press.

Roper, D. C. 1979 The method and theory of site catchment analysig: a review. Advances in Archaeological Hethod and Theory 2:119140 .

Ross, A. 1985 Archaeological evidence for population change in the middle to late Holocene in goutheagtern Australia. Archaeology in Oceania 20(3):81-89.

Roth, W. E. 1909 North Queensland Ethnographic Bulletin. No.13 Fighting Weapons. Records of the Australian Kuseum. 7:189-211.

Sheridan, G. 1979 Tulas and Triodia: a multidisciplinary investigation of the mechanics and antecedents of the Koondi Tuhla and their implications, for prehistory. Unpublished B.A. (Hons) thesis, Australian National University.

Shipman, P., G. Foster and M. schoeninger 1984 Burnt bones and teeth: àn experimental atudy of colour, morphology, crystal structure and shrinkage. Journal of Archaeological science $11: 307-325$.

Short, J. 1982 Habitat requirements of the Brush-tailed rock-wallaby, Petrogale peniciliata, in New South Wales. Aüstralian NildIife Research 9:239-146.

Schrire, c. 1982 The Alligator Rivers: prehistory and ecology in western Arnhem Land. Terra Australis.7. . Department of Prehistory, Research school of Pacific studies, Australian National University.

Solomon, S. 1985 People and other aggravations: taphonomic research in Australia. Unpublished B.A. (Hons) thesis, University of New England.

Southwell, C. 1984 variability in grouping in the Eastern grey kangaroo, Macropus giganteus I. group density and group $81 z e$. Australian Wild1ife Research 11:423-435. 
Southwell, c. 1987 Macropod studies at wallaby Creek II. density and distribution of macropod species in relation to environmental variables. Australian Wildlife Research 14:15-33.

Spencer, B. 1914 Native tribes of the Northern Territory of Australia. London: Macmillan.

Speth, J. D. and K. A. Spielmann 1983 . Energy sources, protein metabolism, and hunter-gatherer subsistence strategies. Journal of Anthropological Archaeology 2:1-31.

Steele, J. G. 1983 Aboriginal pathways. St. Lucia: University of Queensland Press.

Stuiver, M. and P. J. Reimer 1986 A computer program for radiocarbon age calibration. Radiocarbon 28:1022-1030.

Sullivan, H. 1977 Aboriginal gatherings in south-east Queensland. Unpublished B.A. (Hons) thesis, University of Queensland.

Sullivan, M. E. 1982 Aboriginal shell middens in the coastal landscape of New south Wales. Unpublished Ph.D. thesis, Australian National University.

Thomson, J. A. and W. H. Owen 1964 A field study of the Australian

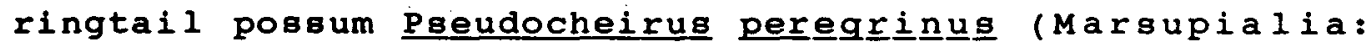
Phalangeridae). Ecological Monographs 34(1):27-52.

Todd, L. C. and.D. J. Rapson 1988 Long bone fragmentation and interpretation of faunal assemblages: approaches to comparative analysis. Journal of Archaeological science $15: 307-325$.

Vita-Finzi, c. and E. S. Higgs 1970 Prehistoric economy in the Mount Carmel area of Palestine: site catchment analysis. Proceedings of the Prehistoric society 36:1-37.

Von Enrt, D. W. and D. J. Ortner 1984 Experimental effects of bone size and temperature on bone diagenesis. Journal of Archaeological science 11:247-253.

Walters, I. 1987. Another Kettle of Fish: the prehistoric Moreton Bay fishery. Unpublished Ph.D. thesis, University of Queensland.

Walters, I. 1988 Fire and bones: patterns of discard. In B. Meehan and R. Jones (eds), Axchaeology with ethnography: an Australian perspective, pp. 215-221. Department of Prehistory, Research school of Pacific studies, Australian National University.

Walters, I., P. Lauer, A. Nolan, G. Dillon and M. Aird 1987 Hope Island: salvage excavation of a Kombumerri site. Queensland Archaeologica 1. Research 4:80-95.

Williams, K. 1984 Native plants of Queensland. Brisbane: Printcraft.

Williams, J. B., G. J. Harden and W.J.F. McDonald 1984 Trees and shrubs in rainforests of New south wales and southern Queens 1 and. Botany Department, University of New England. 